\title{
Information and Communications Technologies (ICT) and Multimedia Technologies in Art and Culture
}

\author{
Nikolay V. Borisov*, Artem A. Smolin, Denis A. Stolyarov*, \\ Pavel P. Shcherbakov and Vasiliy A. Trushin \\ ITMO University \\ 49 Kronverksky pr., St. Petersburg, 197101, Russia \\ Saint Petersburg State University \\ 7/9 University Embankment, St. Petersburg, 199034, Russia
}

Received 17.03.2016, received in revised form 24.05.2016, accepted 19.06.2016

In this article, through the example of the projects of the Centre of Design and Multimedia of ITMO University the possibilities of using a variety of equipment and software in various fields of culture and art are demonstrated. Information and multimedia technologies have given opportunity comprehensively enrich different creative and cultural industries and arts, introduced more possibilities into creative projects to create a special creative atmosphere and a deeper and more emotional perception of creative content.

Keywords: Keywords: multimedia, culture, Internet Theater, multimedia $360^{\circ}$, virtual reality.

DOI: 10.17516/1997-1370-2016-9-7-1661-1667.

Research area: culture studies.

\section{Introduction}

Museums, theaters, libraries and other cultural institutions for a long time feel at ease in the paradigm of the information society. Information technologies in all their diversity actively contribute to the processes of education, cognition and various game practices.

Modern theater directors and playwrights, actively using multimedia technology in their performances are looking for new ways of communication with the audience.

One of the vivid examples of modern theater production that uses cutting-edge technologies is a theatrical production "Neurointegrum" (http://art1.ru/teatr/nauka-illyuzii-kak-illyuziyanauki/), set at the New Stage of Alexandrinsky Theatre (Fig.1).

"Neurointegrum" is a media performance where the emotional state and a set of mental commands used by the actor to operate audiovisual algorithms of production act as a performing instrument. The system of tracking movement and gesture recognition is used as well. The whole production is automatically generated in real time.

Multi-projection - stage is represented by two screens sized $10 \times 4.5$ meters for graphical projections (without the use of the previously

(C) Siberian Federal University. All rights reserved

* Corresponding author E-mail address: nikborisov@gmail.com; denis1900@mail.ru 


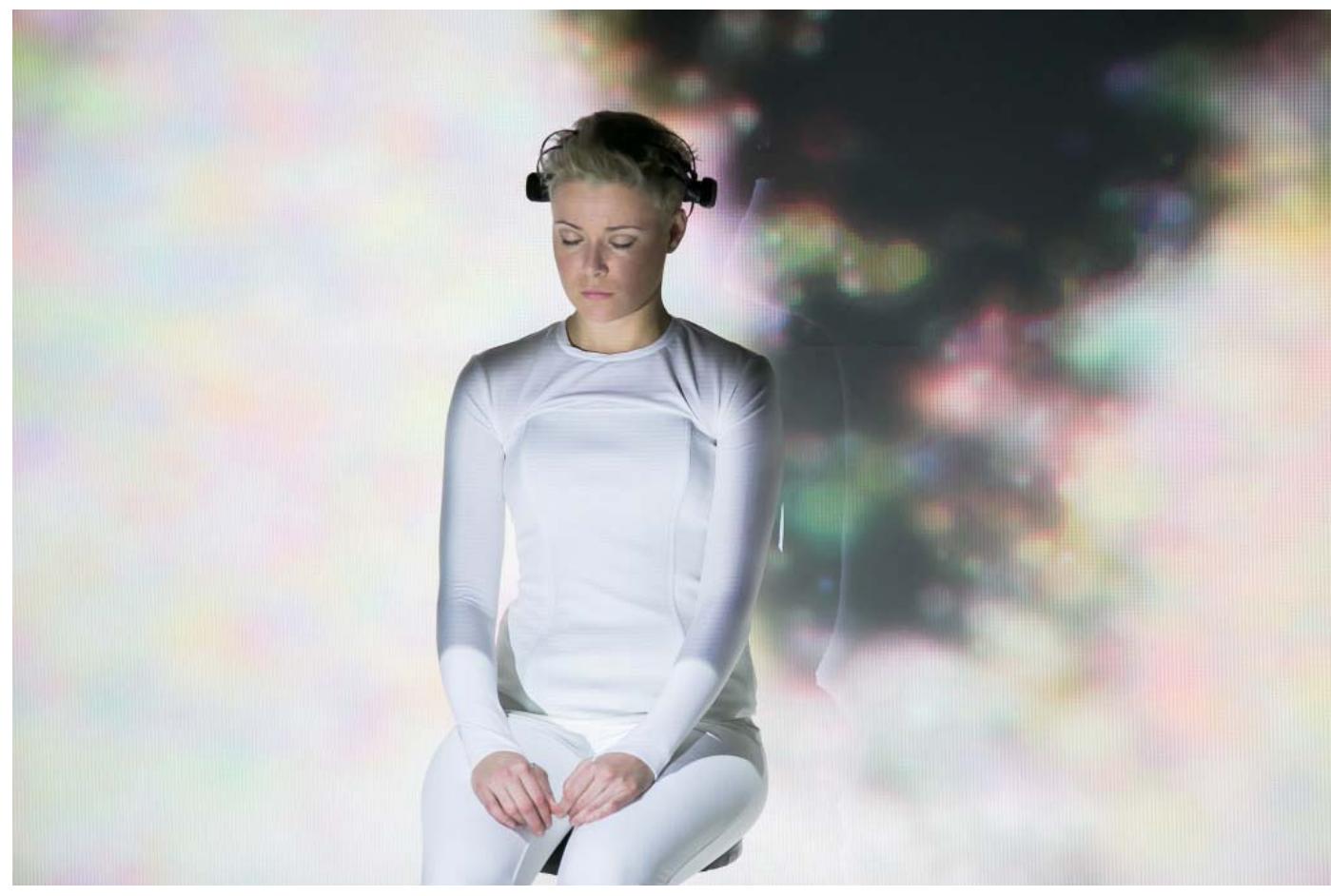

Fig. 1. Neurointegrum performance. Production Director Yury Didevich

recorded video - the graphics is generated in real time), and a separate projection on the performer's silhouette.

Multi-channel surround sound - fourteen audio channels and two subwoofers are used in the performance, all are separated and used for the psychoacoustic and surround effects. Additionally, for gesture recognition, IR camera and Microsoft Kinect are used; there is also Clay Paky A.leda Wash K20 lighting fixture, which is interactively controlled by the performer's head in one of the scenes.

The performance is operated by four computers: two personal computers to generate projections (onto the floor, in the rear projection screen and onto the performer's silhouette), one iMac computer with the installed Windows system to work with neural interface Emotiv Epoc and Microsoft Kinect, as well as one Mac to generate sound. The sound of the performance is also generated in real time, including surround effects.

\section{Multimedia Technologies in Theatre Activities}

In 2013, in Saint Petersburg, the staff of the Centre of Design and Multimedia of ITMO University took part in the opening of the theater and cultural complex "The New Stage of Alexandrinsky Theatre". One of the main concepts of the complex is active use of modern multimedia technologies in theatrical productions.

Withinopeninga famousfilm director Andrey Moguchy used the works of the great Russian writer Fyodor Mikhailovich Dostoyevsky.

"New technologies. They return us to the modern man. We are taking the essence of the technology-a new structure of thinking, a new attitude to space and time.

We will start testing of the New Stage with the key figure of civilization, the bearer of the code of nation - Dostoevsky (//test.thenewstage. ru/ru/project/21/tc-dostoevskiy)".

Within the frames of the site opening the use of various technological devices, as well as 


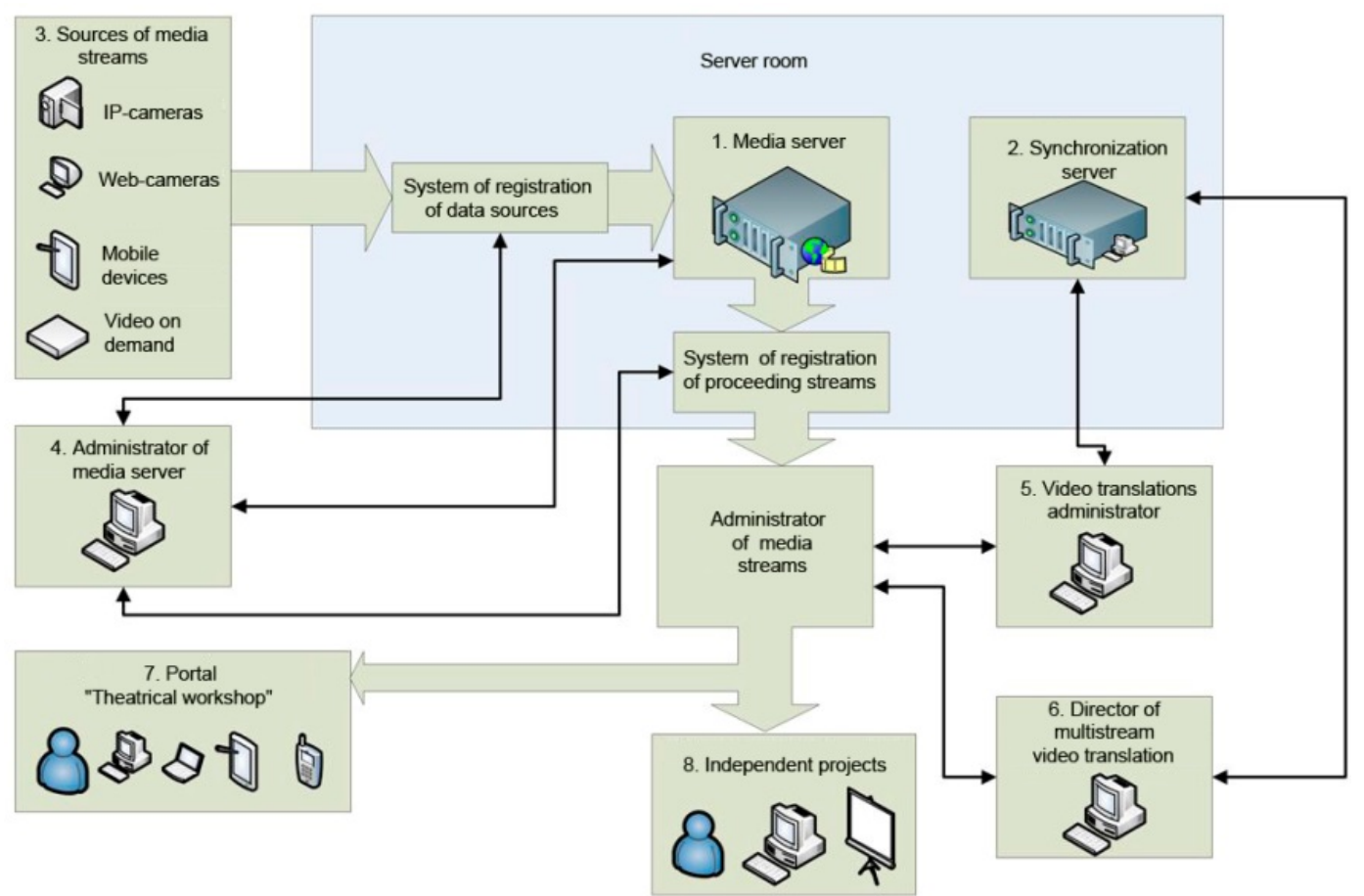

Fig. 2. Graph of the multipurpose hardware and software system of the New Stage of Alexandrinsky Theatre

the creation of various software and hardware complexes was of a dual nature.

On the one hand, the task to implement technological solutions that enable to provide information services to the New Stage of Alexandrinsky Theatre was set to the engineers of the Research ITMO University, and on the other hand it was necessary to introduce a variety of hardware and software complexes as the stage design for the performance.

A multifunctional hardware and software complex (Fig.2), which allows carrying out online viewing of the theater and other thematic events (lectures, workshops, etc.) [3] has become one of the implemented projects.

The following interrelated objectives were set and implemented:

1. Capture and delivery of a few highquality video streams to the viewer at the same time;

2. Flexible connection of various sources of video streams and their prompt redirection;
3. Remote diagnostics of the state of the video streams sources;

4. Configuration and rational planning of the network infrastructure use to ensure regular stable operation of the whole system.

The algorithm of the hardware and software complex operation (Borisov, 2013) media streams received from various devices (IP-camera, web cameras, video cameras and video streams that are used for retranslation from other media servers, etc.), through the local computer network of the New Stage of Alexandrinsky Theatre are transmitted for processing to the media server, located near the core of the computer network of the New Stage. Due to the open architecture of the selected software for the media server (Media Server Wowza v.3.4), plug-in written in Java was developed and connected to the media server, which allowed to develop the system of media data sources registration through the Web. Using it, the media server administrator 


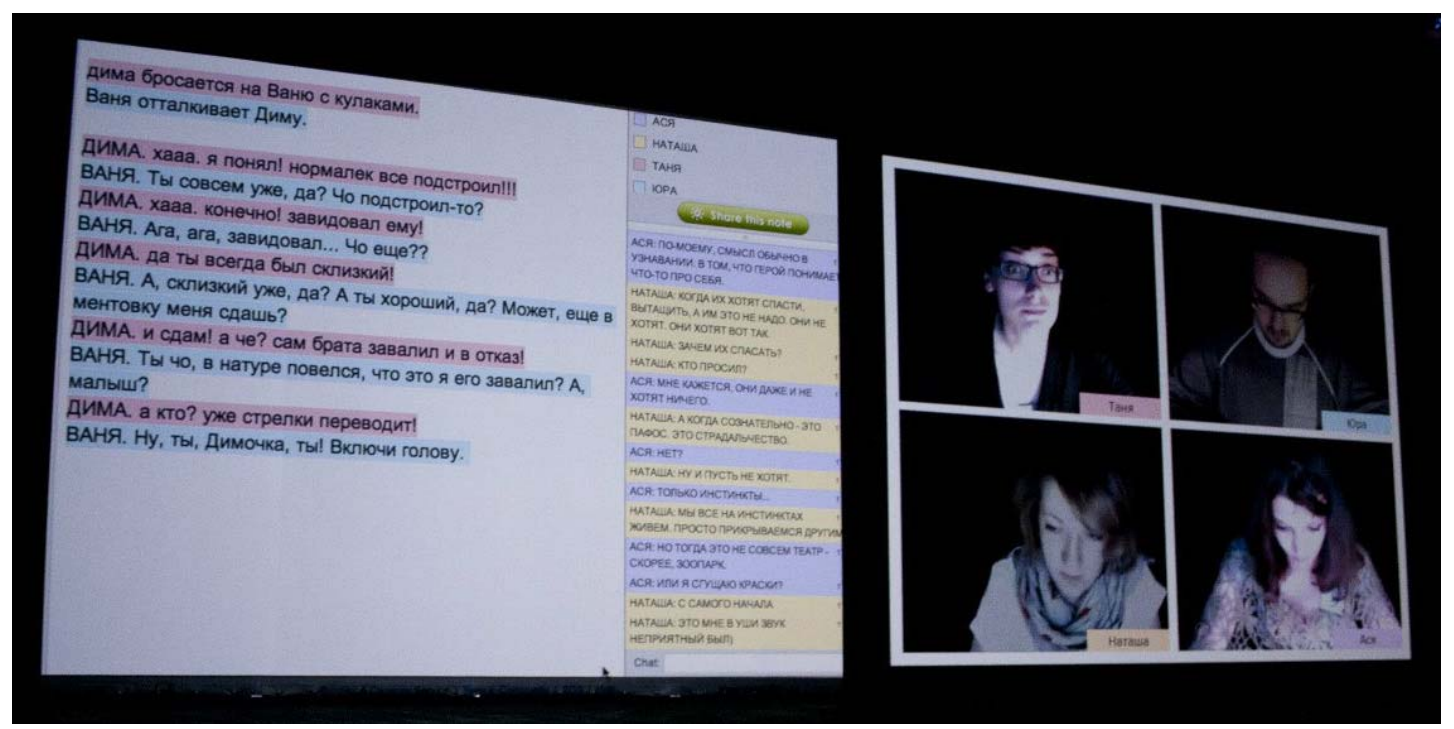

Fig. 3. The fragment of NET DRAMA performance

has the ability to register any of the media data sources, to verify its condition and make it available at the media server, as well as to create sets of the desired quality video streams from any registered media data sources and promptly manage their translation, recording and configuration.

Information of the outflow streams registration system is transmitted to the video translations administrator that handles all the video and audio streams, forming a grid of the projects broadcasting and decides which audio and video streams will be available to directors who work with specific projects.

The direction of the software and hardware complexes use as part of the performance itself can be referred to the so-called non-trivial objectives in the use of modern technologies in theatrical productions.

One of such projects at the opening of the New Stage of Alexandrinsky Theater was the theater of text - the "NET DRAMA" project (Fig.3) Borisov, 2013).

The conception of this project is that the process of writing a script for a new play becomes the subject of a theatrical performance. Four young playwrights, right in front of the spectators' eyes, simultaneously wrote the script of the modern interpretation of the work by Fyodor Mikhailovich Dostoyevsky “The Brothers Karamazov”.

Through the use of two projectors the audience watched three components of the performance:

1. Immediately, the programme itself, for writing the script simultaneously by four participants in real time with highlight colours;

2. Chat, which allowed to comment on the written and give comments in response to the cries of the spectators from the audience, which contributed to the creation of a good communication environment between the audience and the playwrights;

3. A visual component - to broadcast the playwrights' faces in the process of their work.

Thus, an application with an intuitive interface, visually representing the whole process of collective work was developed.

As a result of implementing a number of projects on implanting information and multimedia technologies, the team of ITMO University, in collaboration with the colleagues from theatres have formed a number of principles 
of the modern Internet-theater (Borisov, Internet and Multimedia..., 2015):

1. Various creative projects (shows, performances, video art) that use informationcommunication- multimedia and other technologies;

2. Multi-stream online broadcasting of shows with various interactive elements (voting, chat, screen management, etc.);

3. Interactive performances with the direct participation of Internet users;

4. An archive of previous stage productions with the option of watching them online.

\section{Multimedia $360^{\circ}$ Technologies}

One of the promising directions, which started being actively used in culture and art, is the technology of video recording in the $360^{\circ}$ format.

Employees of the Center of Design and Multimedia of ITMO University have developed a specialized camera to record $360^{\circ}$ video (http:// video360production.com/). Content created with the help of this equipment can be viewed with a variety of virtual reality headsets (Oculus Rift, Samsung
Gear VR, Homido, etc.), as well as on various mobile devices and from the monitor screen.

With the help of the created equipment recordings of various concerts, musical, cultural and special events were carried out (Mariinsky and Alexandrinsky theaters, Peter the Great's Museum of Anthropology and Ethnography "Kunstkamera", band "Picnic", Jazz Philarmonic Orchestra and band "Leningrad"), recorded a number of excursions in cooperation with Solovetsky State Historical-Architectural and Natural Museum-Reserve". Figure 4 shows the recording of excursions on the rivers and canals of St. Petersburg in $360^{\circ}$ Video format (Borisov, Ispol'zovanie tekhnologii...., 2015).

In addition to the passive viewing of the created content, there is a possibility to create interactive $360^{\circ}$ video, with an option to continue viewing using various devices (a mouse, joysticks and motion capture devices) or active virtual tags placed directly in the space of video material. Besides, introduction of different content of "picture in picture function" into $360^{\circ}$ video, as well as the transition to the simulated 3D space is possible as well.

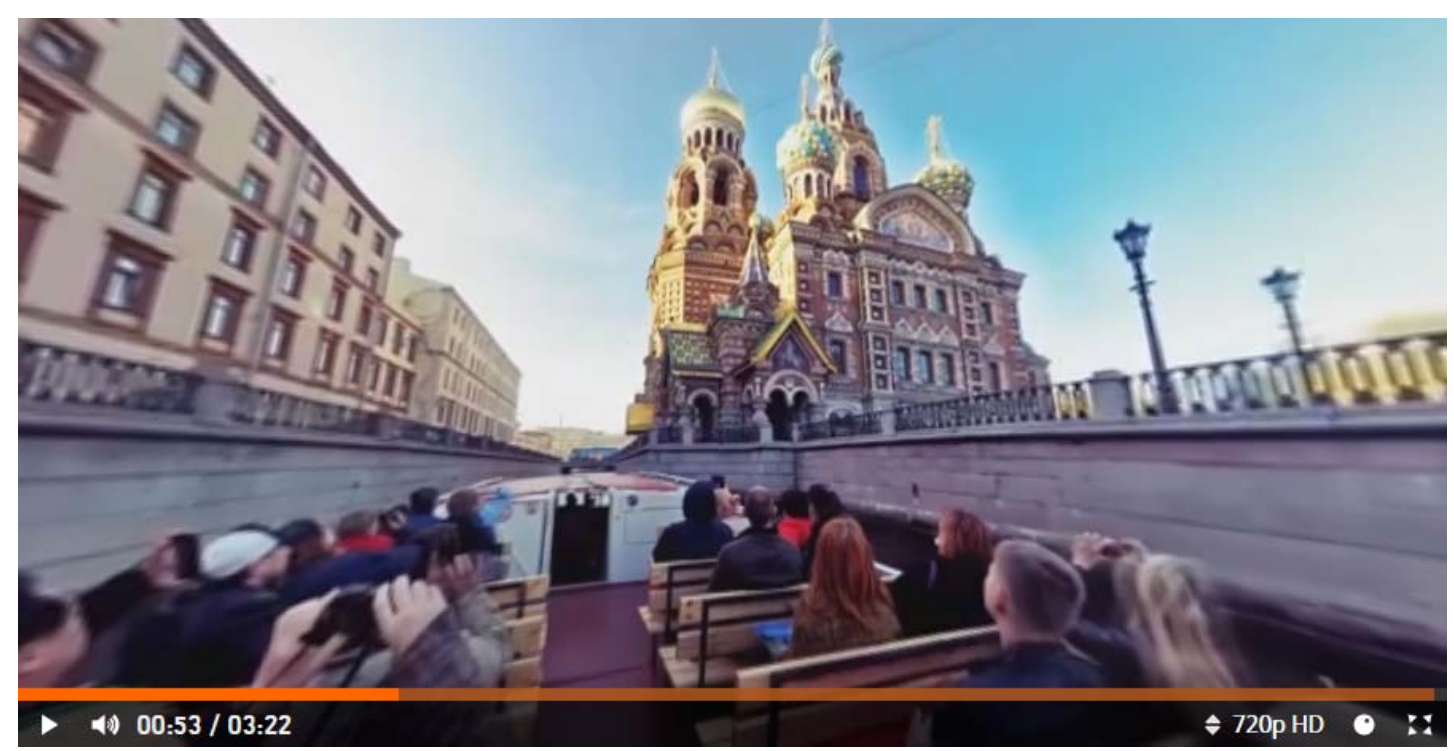

Fig. 4. A fragment of the tour on the rivers and canals of Saint Petersburg in $360^{\circ}$ video format 
Within continuing work on the grant of the Russian Humanitarian Foundation "Multimedia Information System "Ancient Fortress of the North-West of Russia", the Center of Design and Multimedia employees have created a prototype of interactive tour of Korela Fortress Museum (Borisov, Multimedia $360^{\circ}-$ New Technology ..., 2015).

\section{Resume}

The information society is inconceivable without the use of computer technologies that find reflection in all kinds of activities. And creative activity is not an exception. Information and multimedia technologies introduced into any creative product are designed not to compete and not to resist the classical works, but to create a decent alternative, as they bring new experimental approaches and new ways of perception.

This work was partially financially supported by Government of the Russian Federation, Grant 074-U01.

This work was partially financially supported by Saint-Petersburg State University development program.

\section{References}

Nikita, S. Nauka kak illiusiia nauki [Science as an Illusion of Science]. Available at: http://art1.ru/ teatr/nauka-illyuzii-kak-illyuziya-nauki/

TTs "Dostoevskii" Forum-otkrytie Novoi stsen y Aleksandrinskogo teatra [TC "Dostoevsky" Forum-Opening of the New Stage of Alexandrinsky Theatre]. Available at: http://test.thenewstage.ru/ $\mathrm{ru} /$ project/21/tc-dostoevskiy

Borisov, N., Smolin, A., Stolyarov, D., Shcherbakov, P. [2014]. Interactive Internet Theatre (Interactive Multimedia Solutions at the New Aleksandrinsky Theatre Stage), In Lecture Notes of the Institute for Computer Sciences, Social Informatics and Telecommunications Engineering. 145, 100108.

Borisov, N., Smolin, A., Stolyarov, D., Shcherbakov, P. [2013]. Interactive multimedia solutions Developed for the Opening of the New Stage of the Alexandrinsky Theatre, In Proceedings of the Third International Conference Digital Presentation and Preservation of Cultural and Scientific HeritageDIPP2013. Veliko Tarnovo, Bulgaria, September 18-21. (III), 153-159.

Borisov, N., Smolin, A., Stolyarov, D., Tscherbakov, P. [2015]. Internet and Multimedia Technologies for the Theater Performances, In Eva 2015 Saint Petersburg. Electronic Imaging \& the Visual Arts International Conference, St. Petersburg, June 24-25, 2015 Conference Proceedings. SPb ITMO University, 163-169.

Project Video 360 production. Available at: http://video360production.com/

Borisov, N.V., Smolin, A.A., Stolyarov, D.A. [2015]. Ispol'zovanie tekhnologii multimedia $360^{\circ}$ $\mathrm{v}$ kul'ture i iskusstve [Use of Multimedia $360^{\circ}$ Technologies in Culture and Art], In Informatsionnye sistemy dlia nauchnykh issledovanii: Sbornik nauchnykh statei. Trudy XVIII ob'edinennoi konferentsii "Internet i sovremennoe obshchestvo" [Information Systems for Scientific Researches: Collection of Scientific Papers. Proceedings of the 18 ${ }^{\text {th }}$ Joint Conference "Internet and Modern Society"]. Saint Petersburg, 23 - 25 June 2015. SPb., 184-196.

Borisov, N., Smolin, A., Stolyarov, D. [2015]. Multimedia 360 - New Technology for Arts and Culture, In Eva 2015 Saint Petersburg. Electronic Imaging \& the Visual Arts International Conference, St. Petersburg, June 24-25, 2015 Conference Proceedings. SPb ITMO University, 18-31. 


\title{
Информационные и коммуникационные технологии (ИКТ) и мультимедийные технологии в искусстве и культуре
}

\author{
Н.В. Борисов, А.А. Смолин, Д.А. Столяров, \\ П.П. Щербаков, В.А. Трушин \\ Университет ИТМО \\ Россия, 197101, Санкт-Петербург, Кронверкский пр., 49 \\ Санкт-Петербургский государственный университет \\ Россия, 199034, Санкт-Петербург, Университетская набережная, 7/9
}

\begin{abstract}
В данной статье на примере проектов Центра дизайна и мультимедиа Университета ИТМО продемонстрированы возможности использования различного оборудования, а также программного обеспечения в различных областях культуры и искусства. Информационные и мультимедиа технологии позволили всесторонне обогатить различные креативные и культурные индустрии и искусства, привнесли в проекть больше возможностей для создания особой творческой атмосферы и более глубокого и эмоционального восприятия творческого контента.
\end{abstract}

Ключевые слова: мультимедиа, культура, интернет-театр, мультимедиа $360^{\circ}$, виртуальная реальность.

Научная специальность: 24.00.00 - культурология 